\title{
新型手性杯 $[4]$ 氮杂冠醚衍生物的简便合成及其 对甲醇分子的包结行为
}

李正义 ${ }^{(1)}$, 滕明瑜 ${ }^{(1}$, 马洁洁 ${ }^{(1)}$, 黄吉 ${ }^{(1)}$ 王乐勇 ${ }^{\mathbb{*} *}$, 潘毅 ${ }^{(1 *}$

(1) 南京大学化学化工学院, 介观化学教育部重点实验室, 南京, 210093

(2) 徐州医学院, 徐州 221004

* 通讯作者, E-mail: lywang@nju.edu.cn; yipan@nju.edu.cn

收稿日期：2008-11-12；接受日期：2008-12-22

doi: 10.1007/s11426-009-0045-8

全文见: Science in Chinese Series B: Chemistry, 2009, 52(4): 497-504

摘要本文报道新型手性杯 $[4]$ 氮杂冠醚衍生物的简便合成. 即在路易斯酸 $\left(\mathrm{ZnCl}_{2}\right)$ 催化下，二氧基取代杯[4]芳烃与各种光学活性的 1, 2-氨基醇反应, 高产率得到了手 性杯[4]氮杂冠醚衍生物. 该方法具有反应条件温和、操作简便、产率高等特点. 产 物的晶体 X-行射及 ESI-MS 数据表明, 通过主客体之间的 $\mathrm{O}-\mathrm{H} \cdots \pi$ 作用, 杯芳烃上沿 的空腔对甲醇分子具有较强的包结作用。

关键词

手性杯[4]氮杂冠醚

1,2-氨基醇

晶体结构解析

包结络合物

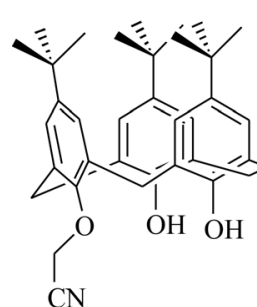<smiles></smiles>

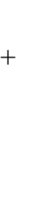<smiles>[R]C(N)C([R])O</smiles><smiles>[R]OC(C)(C)Cl</smiles>

$\mathrm{R}_{1}=i-\mathrm{Pr}, \mathrm{Ph}, \mathrm{CH}_{2} \mathrm{Ph}, \mathrm{Me}$ $\mathrm{R}_{2}=\mathrm{H}$

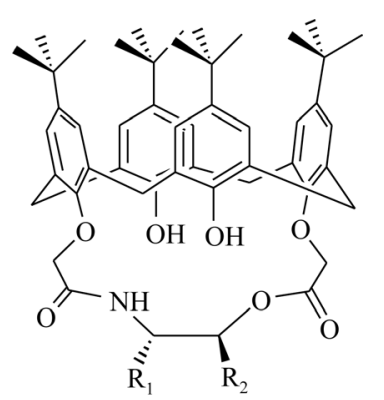

